The Canadian Journal of Higher Education, Vol. XXIII-1, 1993

La revue canadienne d'enseignement supérieur, Vol. XXIII-1, 1993

\title{
Myths Revisited
}

\section{G. PATRICK O'NEILL*}

\section{Abstract}

Do universities reward teaching? Do universities reward publication? Which is rewarded more: teaching or publication? Do research and publication undermine good teaching? These questions, perhaps more than any others, spark emotional outbursts among academics. Many are quick to champion a view, but their arguments often fly in the face of hard data. What then do the data show? Are they exhaustive? Are they uniform? One set of answers is found in Professor Johnston's article entitled, "Myth Conceptions of Academic Work" which appeared in the Canadian Journal of Higher Education, Vol. XXI-2, 1991. Another set is found in this article. The reader is left to draw his or her own conclusion.

\section{Résumé}

Quelles reconnaissances les univesités accordent-elles à l'enseignement? Encouragent-elles la publication? L'une de ces activités est-elle davantage valorisée que l'autre? La recherche et la publication contribuent-elles à diminuer la qualité de l'enseignement? Ces questions, peut-être plus que toutes autres, soulèvent des flambées d'emotion chez les enseignants. Plusieurs n'hésiteront pas à énoncer un point de vue même si ces arguments sont souvent contredits par les données statistiques. Que démontrent donc ces données? Sont-elles exhaustives? Sont-elles cohérentes? Un article de Ian C. Johnstone paru dans la Revue canadienne pour l'enseignement supérieur, vol. XXI-2, 1991, et intitulé "Myth Conceptions of Academic Work, a tenté de répondre à ces questions. Cet article soumet un autre point de vue. Les lecteurs et lectrices sont appelés à tirer leurs propres conclusions.

\footnotetext{
* Brock University
} 
Ian Johnston's article reopens the debate on the reward structures of universities. He does so in the context of the new university colleges in British Columbia; however, I find his comments to be inaccurate and misleading in at least four areas. The purpose of this reply is to examine each in turn.

First, Professor Johnston claims that advancement in universities hinges solely on research and publication. He states that:

Officially, the university may worry about the quality of instruction and may in ringing policy statements endorse the importance of good teaching, but, in practice, the system rests firmly on the central importance of research publication as the essential requirement. (italics added) (p. 112)

And,

We may have increasing doubts about the coherence and purpose of much [sic] what goes on in the university, but those inside commit their energies to publishing because that is the basic rule of the profession. We teach graduate students the principle, we hire and promote faculty on the basis of their research qualifications and activities, ... (italics added) (p. 114)

Yet, nothing could be further from the truth. Most professors do not publish (Boice \& Jones, 1984; Crase, 1987; Jalongo, 1985; Powell, 1985; Youn \& Zelterman, 1988). In particular,

...over 52 per cent of the full-time academics have never written or edited any publication; more than one-third have neither written nor edited since receiving their Ph.D.s. J. Cole's study (1979) also supports this general pattern of skewed research productivity among academics. One to two years after obtaining a doctorate, 53 per cent have failed to publish a single paper and 34 per cent have published only one. In most years, three-quarters publish nothing. (Youn \& Zelterman, 1988, p. 63)

Obviously, the old "publish or perish" maxim is a myth (O'Neill, 1990). If the maxim were true, few professors would ever be tenured or promoted. How then do most faculty gain tenure and promotion? The answer leads to my second point.

Most universities use a tripartite model where tenure and promotion decisions are based on three factors, not one as Professor Johnston argues. The three factors are: (1) teaching ability, (2) publication record, and (3) service. Service includes such activities as committee work, administrative duties, program 
development, and so forth. As a rule, teaching and publication are considered to be primary criteria, while service is considered secondary (Rogers, 1982). In other words, you must excel in either teaching or publication, or both to gain tenure and promotion. The service component can strengthen, but not necessarily weaken, a candidate's position. And, this leads to my third point.

If, as evidence indicates, most faculty do not write and publish, then contrary to what Professor Johnston maintains, teaching must be rewarded. How else could faculty gain tenure and promotion? Surely, decisions are not based on service alone. Granted, they may be in the case of some career administrators who simply negotiate their lot as part of a package (a practice I deplore and one which universities should stop); but most professors must pass through the ranks.

Of course, the relative importance of teaching, as opposed to publication, varies widely both within and across institutions. For example, teaching is generally stressed in small undergraduate degree-granting programs; whereas publication is stressed more heavily in Ph.D.-granting programs (Boyes, Happel \& Hogan, 1984). Thus, it is nonsensical to claim, at least in absolute terms, that teaching is not rewarded. It is rewarded, but the degree of reward depends on the school, its size, its mandate, and so on.

Still, the question remains. Overall, which of the two is rewarded more: teaching or publication? Professor Johnston sides with publication. I side with teaching. I say this because writing entails personal sacrifice that goes beyond teaching. It is hard work. It is time consuming. There are no short cuts. The idea may be glamorous, but the work is mundane. Others have come to the same conclusion:

...the assistant professor is not likely to put in the lonely, monotonous work of research and writing, only to face the inevitable editorial rejections and negative critical evaluations, if he [sic] perceives his work as being neither supported nor recognized by his employer. Given the alternative demands on faculty time and energy made by a teaching-oriented liberal arts college, productive scholarship may well demand twelve-hour days on a regular basis. When long hours are combined with the naturally limited research facilities of a college and the frustrating dependence on interlibrary loan and similar programs, many academics may decide that the obstacles to scholarship are too great to overcome. Student contacts in and out of class and various forms of campus involvement offer more direct and immediate gratification without the risks of humiliation or the agonizing loneliness of scholarship. (Showalter, 1978, p. 171) 
In addition, there is a cost factor. You get paid directly for teaching overload, but not for publishing. Most journals do not pay for manuscripts. You may even be asked to subsidize publication costs out-of-pocket. Author fees or page charges, as they are called, have become common, particularly in the last ten years. Add to this the loss of potential outside consulting fees and you can see why so few partake. The personal sacrifice is just too great.

My fourth point is related to Professor Johnston's remarks concerning the relationship, or lack of relationship, between research and publication, on the one hand, and teaching on the other. He states that:

...many empirical studies in the last twenty years indicate conclusively that the claims about the creative links between academic research, publication, and teaching have no basis in fact. ... Summaries of research by Webster (1985) and later Neill (1985; 1989) stress the conclusion reached by every reliable study of this matter in the past thirty years: there is no evidence to support the view that academic research and publication have a beneficial effect upon instruction. (italics added) (p. 112)

Yet, according to Jalongo (1985), the evidence is not so one-sided as Professor Johnston would have us believe. In reviewing the literature Jalongo found studies that, "... corroborated the assertion that published faculty perceive themselves, and are perceived by others, as more effective classroom teachers" (p. 173). Jalongo admits, however, that the research, to date, is inconclusive, mainly as a result of definition problems. How, for instance, do you define effective teaching?

The most plausible conclusion, at least at this stage, is, no doubt, that reached by Feldman (1987). He states that:

An obvious interpretation of these results is either that, in general, the likelihood that research productivity actually benefits teaching is extremely small or that the two, for all practical purposes, are essentially unrelated. In either case, an important conclusion would be that productivity in research and scholarship does not seem to detract from being an effective teacher. (p. 275)

Translated, the publisher, on average, is no better or no worse a teacher than the nonpublisher. Accordingly, this means that:

High producers of research, compared with low producers, are no less likely (nor any more likely) to be friendly in class, to show concern for students, to encourage discussions, to be open to others' opinions, or to be sensitive to class level and progress. Nor are they 
more likely - indeed, they may be a little less likely - to be intellectually narrow and to assign course material that is either overly specialized or overly sophisticated for students. (Feldman, 1987, p. 278)

In conclusion, there are two myths here, one of which Professor Johnston appears aware, the other of which he does not. The first deals with the "publish or perish" dictum. Professor Johnston seems to believe, and I might add naively, that, in practice, universities only reward publication; that teaching is not rewarded. This is a misbelief, one that I correct and qualify.

The second myth deals with the link between publication and teaching. Again, Professor Johnston errs in his thinking. First, he concludes that research and publication have no "beneficial" effects on teaching. I concur, but the evidence is not unanimous. Second, he falsely assumes that, if the effects are not beneficial, they must be detrimental. But the literature does not support this view. Rather, the studies show that the two are "essentially unrelated"-that neither has an effect on the other. Being good or bad (however measured) at one does not preclude being good or bad at the other. Hence, the quality of teaching will not necessarily deteriorate should the colleges adopt a model that stresses research and publication. This option, though, seems highly unlikely, given that most small undergraduate schools stress teaching. The point is that, either way, Professor Johnston's fears are unfounded. Excellent teaching, however defined, can, and probably will be, maintained in the new university colleges of British Columbia.

\section{References}

Boice, R. \& Jones, F. (1984). Why academicians don't write. Journal of Higher Education, 55, 567-582.

Boyes, W. J., Happel, S. K., \& Hogan, T. D. (1984). Publish or perish: Fact or fiction? Journal of Economic Education, 15, 136-141.

Crase, D. (1987). Dimensions of scholarly productivity. Physical Educator, 44, 282-290.

Feldman, K. (1987). Research productivity and scholarly accomplishment of college teachers as related to their instructional effectiveness: A review and exploration. Research in Higher Education, 26, 227-298.

Jalongo, M. R. (1985). Faculty productivity in higher education. Educational Forum, 49, 171-182.

O'Neill, G. P. (1990). Publish or perish: Dispelling the myth. Higher Education Review, $23,55-62$.

Powell, J. P. (1985). Browsings. Higher Education Research and Development, 4, 109-110.

Rogers, W. T. (1982). Canadian educational research: Our responsibility. CSSE News, 9, Special 1-7. 
Showalter, D. E. (1978). Publication and stagnation in the Liberal Arts college. Educational Record, 59, 166-172.

Youn, T. I. K. \& Zelterman, D. (1988). Institutional career mobility in academia. In D. W. Breneman \& T. I. K. Youn (Eds.). Academic labor markets and careers (pp. 52-73). New York, N.Y.: The Falmer Press. 